\title{
Status and Condition of Corporatization Strategies of State Universities and Colleges (SUCs) in Region III in the Philippines
}

\author{
Dr. Arneil G. Gabriel (Corresponding author) \\ Program Chair, Department of Public Administration, NEUST, Philippines
}

Dr. Jocelyn B Cruz

Dean, Graduate School, NEUST, Philippines

Received: April 25, 2018 Accepted: June 5, 2018 Online published: June 18, 2018

doi:10.5296/jpag.v8i2.13294ＵRL: https://doi.org/10.5296/jpag.v8i2.13294

\begin{abstract}
The right to free access to quality education of citizens extends to tertiary level education. This Constitutional provision creates increasing demands for State Universities and Colleges (SUC's) which in turn exerts pressure on the budgetary capacity of the government to finance such education. To strike the balance between equity of access and quality of education, SUCs employed corporatization strategies to generate income and finance its operations. The study looks into the strategies employed by SUCs in Region III in the Philippines and analyzes matters related to the practice of corporatization principles. By using descriptive correlation design, the study showed that respondent SUCs in Region III are: a) diverse in many aspects of their operations, b) vary in the modes of generating income, descriptively measured from "sometimes" to "often" except the collection of tuition fees which has been rated as "very often" applied as corporatization strategy, c) have variety in income utilization ranging from 46 percent to 51 percent; d) stakeholders are found "very satisfied" in the manner SUCs in Region III used their income, e) are rated with varying interpretations in terms of corporatization strategies and performance of their fourfold functions, e) have marked differences in terms of income utilization except in corporatization activities which marked as "not significant". Finally, it was found that employees' satisfaction and the performance of the four fold functions of instruction, research, extension and production are significantly correlated. It is recommended that stakeholders' engagement in planning and organizing programs and projects of SUCs in Region III be enhanced.
\end{abstract}

Keywords: Corporatization, State Universities and Colleges, SUCs, Educational 
Management, Public Institution, the Philippines

\section{Introduction}

Education in the Philippines is an expression of parental love. That explains why every parent in the country dreams of sending their children to college and why parents are willing to sacrifice for their children to earn a degree.

The high value that parents place on education is embedded in Filipino culture. So much so that lawmakers made it explicit in Article 14, Section 1 that the State shall promote and protect the right of all citizen to quality education at all levels and shall take appropriate action to make such step accessible to all (Alvaran, 2002).

The number of SUCs in the country however does not suffice for the growing number of enrolees in the college level. Consequently, more SUCs were put up requiring a huge budget allocation exerting pressure to the country's treasury. Today, the Philippine higher education is at a crossroads to economic globalization where privatization, deregulation and corporatization are the guiding principles of new global economic order (Fronda et al., 2017). Thus, SUCs find themselves in a more competitive and challenging local and global environments. The challenges emanated from: First, liberalization policies of the Commission on Higher Education (CHED) as shown by the lifting of moratorium in the course offered . Secondly, the increase in the number of SUCs has affected the budget allocation from the government for each of the institution (Villabroza, 2002).

It was then that the idea of corporatization came about. Corporatization of SUCs in the Philippines is stipulated under Republic Act 8292, also known as the Higher Education Act of 1997. It allows SUCs to engage in corporate activities in order to generate revenues. It empowers the governing boards of SUCs to retain income and enter into joint ventures with business and industry. The statute further provides the means by which SUCs exercise the powers granted to a Board of Directors of a corporation under the Corporate Code of the Philippines (Batasan Pambansa Number 68). This is in preparation for the gradual withdrawal of government support to the SUCs Maintenance and Other Operating Expenses (MOOE) or the allocated budget for the SUCs maintenance and other operating expenses which used to be shouldered by the government.

While corporatization is perceived as a means of financial autonomy, it is also believed that it may have impact on the schools delivery of services, although its effects and influences have yet to be ascertained.

On the other hand there were indications that corporatization did no good in the education system. Public opinion supports this, to wit:

"The most significant change has been higher education's attempt to become a lean and mean money-making 'industry' instead of an institution with an important social and educational mission that served the nation and the world. The corporatization of the university is the end of the public university (I say 'public' because I think that 
private institutions, less battered by political winds and the funding whims of state legislatures, will probably maintain some semblance of this mission). The mission of the higher education institutions that I was educated to teach in was not to produce trained cogs for the corporate machine, but to produce independent, critical thinkers who are equipped to leave the world better than they found it. (http://www.insidehighered.com)

Another critique of corporatization is the increase in the number of administrators. According to Mills (2002), the number of full-time faculty at colleges and universities in the United States has grown by 50 percent over the 40 years. This is because of the increase in student enrolment. However, the number of administrators has risen by 85 percent and the number of staff required to help the administrators has increased by 240 percent. There is no doubt that there are so many policy decisions at colleges and universities which are made without faculty inputs. The dramatic increase in the number of school administrators in the US is different from the Philippine Experience.

The Philippines as a state provides free education in the elementary and high school levels. This is explicitly stated in Article 14, Section 2 of the 1987 Philippine Constitution. Education in these levels is free because it is the government that provides for the budget necessary for their operation( Gabriel and Claudio,2016). In tertiary education, however, government support is not as intensive although there are also SUCs that cater to the need of education in the tertiary level. Tuition and miscellaneous fees are not free in the SUCs but definitely these are way below compared with the tuition and miscellaneous fees in private colleges and universities because these institutions are subsidized by the government.

The study was borne out of the proponent's feeling that there was a need for a study that would show the connection between corporatization strategies of SUCs and the SUCs generic function as a means of transfer of knowledge. In this study, the researcher attempted to: describe the SUCs according to number of their programs, enrolment size, number of teaching and non-teaching personnel and average income for the past five years; attempt to determine the income generation strategies of SUCs which included the following: outsourcing or importing services from outside the school, merger which could either be buying or surrendering stocks, joint venture or pooling resources with other parties, school fees like tuition and other fees, and fund raising activities like ticket selling, raffles or the likes; look into the income utilization of the SUCs on the basis of their priorities, namely: instruction, research, extension, production, administrative services, and mandatory reserve; determine the degree of respondents' satisfaction with the way their respective income was utilized; and relate the SUCs performance on the basis of the SUCS fourfold functions, namely: instruction, research, extension and production out of the researcher's desire to determine whether the income utilization has something to do with the way the SUCs perform according to their mandated tasks.

\section{Methodology}

The study used the descriptive correlational research design as much as it attempted to 
describe the status and condition of corporatization at SUCs and correlate the variables of satisfaction with income utilization to the description of the state universities and colleges' four-fold functions. Explicitly, the study measured the following sub variables: a) to describe the profile of the respondents; in terms of a. 1 number of programs, a. 2 enrolment size,a. 3 number of teaching personnel, a. 4 number of non-teaching personnel, and a.5 average income in the past five years; b) describe the modes of income generation being utilized by the state universities and colleges; c) state the ways on how the SUCs utilize their income; and measure the level of satisfaction of the stakeholders with the income utilization of the state universities and colleges; d) describe the four-fold functions of state universities and colleges; e) determine whether there is significant difference among the state universities and colleges in Region III on the basis of their profile, income generation, and income utilization; and respondents' satisfaction in income utilization and their rating for the SUCs performance along their four-fold functions. The respondents to the study are presented below:

Table 1. The Respondents of Study

\begin{tabular}{c|c|c|c|c}
\hline Province & $\begin{array}{c}\text { State Universities and } \\
\text { Colleges }\end{array}$ & Administrators & $\begin{array}{c}\text { Department Head } \\
\text { for Research, Extension } \\
\text { and Training }\end{array}$ & $\begin{array}{c}\text { Academic Area } \\
\text { Heads }\end{array}$ \\
\hline Nueva & CLSU & 3 & 3 & 10 \\
Ecija & NEUST & 3 & 3 & 10 \\
\hline Pampanga & PAC & 3 & 3 & 10 \\
& DHVTSU & 3 & 3 & 10 \\
& PhilSCA & 3 & 3 & 10 \\
\hline Bulacan & BSU & 3 & 3 & 10 \\
& BSAU & 3 & 3 & 10 \\
\hline Tarlac & TCA & 3 & 3 & 10 \\
& TSU & 3 & 3 & 10 \\
\hline Zambales & RMTU & 3 & 3 & 10 \\
& PMMA & 3 & 3 & 10 \\
\hline Aurora & BPSU & $\mathbf{3 9}$ & $\mathbf{3 9}$ & $\mathbf{1 3 0}$ \\
\hline Total & $\mathbf{1 3}$ & & & \\
\hline
\end{tabular}

Meantime, the table below shows the profile of the State Colleges and Universities income utilization ,condition and status, to wit;

Table 2. Summary of SUC Profile

\begin{tabular}{c|c|c|c|c|c}
\hline SUC & $\begin{array}{c}\text { No. of } \\
\text { Programs }\end{array}$ & $\begin{array}{c}\text { Enrolment } \\
\text { Size }\end{array}$ & $\begin{array}{c}\text { No. Of } \\
\text { Teaching } \\
\text { Personnel }\end{array}$ & $\begin{array}{c}\text { No of } \\
\text { Non-Teaching } \\
\text { personnel }\end{array}$ & $\begin{array}{c}\text { Average Income } \\
\text { Generated in the } \\
\text { Last Five Years } \\
\text { (Php) }\end{array}$ \\
\hline CLSU & 50 & 10,296 & 533 & 631 & $175,800,000$ \\
\hline NEUST & 42 & 19,681 & 300 & 137 & $91,775,000$ \\
\hline PAC & 30 & 4,097 & 187 & 208 & $18,000,000$ \\
\hline DHVTSU & 25 & 13,138 & 333 & 88 & $113,073,000$ \\
\hline PhilSCA & 12 & 1,428 & 112 & 78 & $35,000,000$ \\
\hline BSU & 55 & 24,211 & 385 & 92 & $286,260,000$ \\
\hline BASC & 15 & 2,900 & 270 & 81 & $19,290,000$ \\
\hline TCA & 24 & 3,905 & 122 & 128 & $49,842,000$ \\
\hline TSU & 80 & 14,136 & 249 & 222 & $156,968,000$ \\
\hline
\end{tabular}




\begin{tabular}{c|c|c|c|c|c}
\hline RMTU & 45 & 9,137 & 246 & 102 & $72,350,000$ \\
\hline BPSU & 25 & 13,233 & 492 & 302 & $208,836,000$ \\
\hline PMMA & 21 & 2,170 & 58 & 47 & $42,300,000$ \\
\hline ASCOT & 32 & 2,498 & 102 & 71 & $10,200,000$ \\
\hline Grand Total & $\mathbf{4 5 6}$ & $\mathbf{1 0 7 , 6 9 2}$ & $\mathbf{3 3 8 9}$ & $\mathbf{2 1 8 7}$ & $\mathbf{1 , 2 7 9 , 6 9 4 , 0 0 0}$ \\
\hline Grand Mean & $\mathbf{3 5 . 0 8}$ & $\mathbf{8 2 8 4}$ & $\mathbf{2 6 0 . 6 9 2}$ & $\mathbf{1 6 8 . 2 3 1}$ & $\mathbf{9 8 , 4 3 8 , 0 0 0}$ \\
\hline
\end{tabular}

In this study, the following null hypotheses were tested stating that there was no significant difference among state universities and colleges in Region III in terms of profile, income generation, and income utilization and the respondents' description of the fourfold function of SUCs was not significantly influenced by the respondents' satisfaction in terms of income utilization.

To answer all the problems in this research study, a questionnaire was crafted by the researchers. This questionnaire was prepared and validated by research consultant and experts.

The said questionnaire contained of 5 parts:

Part I described the profile of state universities and colleges;

Part II described the corporatization strategies employed in the university;

Part III described how the revenues from corporatization were utilized;

Part IV described the performance of the college or university along the four-fold mandated functions of the state universities and colleges; and

Part V described the satisfaction level of the respondents with the income utilization in their respective college or university.

The researchers also used frequency and percentage in describing the SUC profile, a mean in describing satisfaction level on income utilization and ANOVA in determining the differences among state universities and colleges in Region III on the basis of profile, income generation, and income utilization. When it comes to the relationship between the employees' satisfaction and the four-fold SUCs functions, the Pearson's r Correlation was employed.

To support the respondents' answers in the questionnaire, an interview was conducted. Do During the interview, the researchers asked the following questions: what are the possible IGPs that your school is doing; where does the income of your school come from; are you required to submit your subject syllabi; are the faculty in your university required to undergo researches; are the faculty members provided enough trainings, workshops, and seminars for personal and professional update; and so on.

The researchers also utilized interview technique in clarifying or verifying data. For other data which might prove to be necessary in her study, she also used content analysis using reports and written materials like annual reports, brochures and handouts which the SUCs freely allowed for public consumption. 
2.1 Research Model

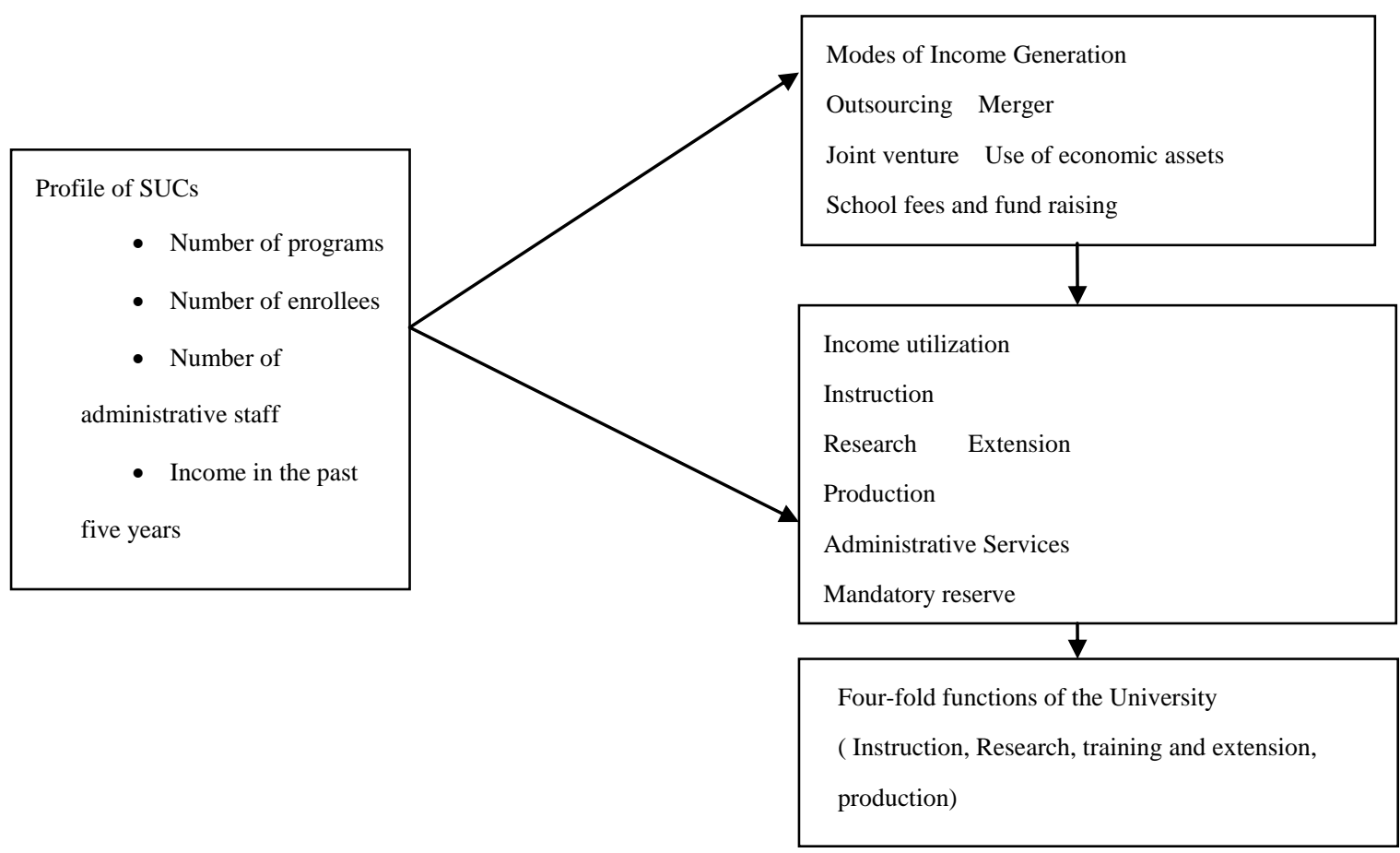

Figure 1. The Model of the Study

\section{Findings and Discussion}

Table 3 shows the profile of respondent State Colleges and Universities in Region III. As the table indicates, SUCs in region III generated a total of $1,279,694,000 \mathrm{PhP}$ of income in the last five years. The smallest income generated is that of Aurora State College of Technology with only 10,200,000.00 income while the highest income is realized by Bulacan State University with 286,260,000.00. The number of students catered by the SUCs varies depending on the size and number of programs. The profile of SUC's in region III in the Philippines is presented below.

Table 3. Summary Table of SUC Profile

\begin{tabular}{l|c|c|c|c|c}
\hline \multicolumn{1}{c|}{ SUC } & $\begin{array}{l}\text { No. } \\
\text { Programs }\end{array}$ & $\begin{array}{l}\text { Enrolment } \\
\text { Size }\end{array}$ & $\begin{array}{l}\text { No. Of Teaching } \\
\text { Personnel }\end{array}$ & $\begin{array}{l}\text { No of Non-Teaching } \\
\text { personnel }\end{array}$ & $\begin{array}{l}\text { Average Income Generated in } \\
\text { the Last Five Years (Php) }\end{array}$ \\
\hline CLSU & 50 & 10,296 & 533 & 631 & $177,800,000$ \\
\hline NEUST & 42 & 19,681 & 300 & 208 & $91,775,000$ \\
\hline PAC & 30 & 4,097 & 187 & 88 & $18,000,000$ \\
\hline DHVTSU & 25 & 13,138 & 333 & 78 & $113,073,000$ \\
\hline PhilSCA & 12 & 1,428 & 112 & 92 & $28,000,000$ \\
\hline BSU & 55 & 24,211 & 385 & 81 & $19,290,000$ \\
\hline BASC & 15 & 2,900 & 270 & 222 & $49,842,000$ \\
\hline TCA & 24 & 3,905 & 122 & 102 & $156,968,000$ \\
\hline TSU & 80 & 14,136 & 249 & 302 & $72,350,000$ \\
\hline RMTU & 45 & 9,137 & 246 & 47 & $208,836,000$ \\
\hline BPSU & 25 & 13,233 & 492 & 71 & $42,300,000$ \\
\hline PMMA & 21 & 2,170 & 58 & $\mathbf{2 1 8 7}$ & $10,200,000$ \\
\hline ASCOT & 32 & 2,498 & 102 & $\mathbf{1 6 8 . 2 3 1}$ & $\mathbf{1 , 2 7 9 , 6 9 4 , 0 0 0}$ \\
\hline Grand Total & $\mathbf{4 5 6}$ & $\mathbf{1 0 7 , 6 9 2}$ & $\mathbf{3 3 8 9}$ & $\mathbf{9 8 , 4 3 8 , 0 0 0}$ \\
\hline Grand Mean & $\mathbf{3 5 . 0 8}$ & $\mathbf{8 2 8 4}$ & $\mathbf{2 6 0 . 6 9 2}$ & & \\
\hline
\end{tabular}


The top state universities which offered the most number of courses were: Tarlac State University (TSU), with the highest number of programs offered with 80 courses; Bulacan State University with 55 courses offered; and Central Luzon State University with 50 courses offered. Philippine State College of Aeronautics got the least number of courses offered (12 courses).As to the size of enrolment, the state universities and colleges varied. Bulacan State University (BSU) got the highest number of enrollees with a total population of 24, 211 students; Nueva Ecija University of Science and Technology (NEUST) with a total of 19, 681 students; and Tarlac State University (TSU) with 14, 136 students. PhilSCA got the least number of enrollees, 1,428 students. In terms of the number of personnel, the result also varied. The Central Luzon State University or CLSU had the highest number with 533; Bataan Peninsula State University (BPSU) got 492 faculty members; Bulacan State University (BSU) had 385; and the institution with least number of personnel wasthe "The Philippine Merchants Marine Academy (PMMA)" with 58 teaching personnel. As to the number of administrative personnel, the 13 state universities and colleges in region 3 also varied. Central Luzon State University (CLSU) still got the highest number of non-teaching personnel with 631; Bataan Peninsula State University (BPSU), 302; Tarlac State University (TSU), 222; and the least was Philippine Merchants Marine Academy (PMMA) with 47 non-teaching personnel. In the amount of income earned, the university with the highest average income in the past five years was Bulacan State University (BSU) with Php. 286,260 000.00; next to it was Bataan Peninsula State University (BPSU) with Php. 208,836,000.00; the 3rd was the Central Luzon State University (CLSU) with Php. 175,800,000.00; and Aurora State College of Technology (ASCOT) had the lowest average income in the past five years with Php.10,200,000.00.

Table 4 presents the manner SUCs in the Region use their income generated from its operations. Income from the collection of school fees remains the largest source of SUC income for the past five years. The complete modes and manner of generating income of SUCs in the region is presented below.

Table 4. Summary of Modes of Income Generation Utilized by State Universities and Colleges

\begin{tabular}{l|c|c}
\hline \multicolumn{1}{c|}{ Modes } & Mean & Interpretation \\
\hline 1. Outsourcing services for the following: & & Often \\
\hline a. catering & 4.16 & Sometimes \\
\hline b. security & 3.21 & Seldom \\
\hline c. janitorial & 2.11 & Sometimes \\
\hline d. electrical maintenance & 3.20 & Sometimes \\
\hline Mean & 3.17 & \\
\hline $\mathbf{2 .}$ Joint venture with other sectors in terms of the \\
following: & & Very Often \\
\hline a. Instruction & & Often \\
\hline b. Research & 4.32 & Sometimes \\
\hline c. Extension & 3.85 & Sometimes \\
\hline d. Production & 2.93 & Often \\
\hline Mean Use of economic assets thru the following. IGPs: & 3.15 & Very Often \\
\hline 3. & & Sometimes \\
\hline a. Space rental $\quad$ Garment Production & 4.24 & 2.71 \\
\hline
\end{tabular}




\section{MInstitute Macroth $_{\text {Int }}$}

Journal of Public Administration and Governance

ISSN 2161-7104

\begin{tabular}{c|c|c}
\hline c. Food Processing & 2.93 & Sometimes \\
\hline d. Agricultural Production & 4.25 & Very Often \\
\hline e. Computing and Printing services & 4.35 & Very Often \\
\hline f. Consultancy services & 2.87 & Sometimes \\
\hline g. Technical Services & 4.32 & Very Often \\
\hline h. Catering Services & 2.54 & Sometimes \\
\hline Mean & $\mathbf{3 . 5 3}$ & Often \\
\hline 4. Income from school fees & & \\
\hline a. Tuition Fee & 4.49 & Very Often \\
\hline b. Miscellaneous Fee & 4.35 & VeryOften \\
\hline c. Parents Teachers Association (PTA) & 4.22 & VeryOften \\
\hline d. Student Government Fee & 4.31 & VeryOften \\
\hline e. Laboratory Fee & 4.44 & VeryOften \\
\hline f. Athletics Fee & 4.36 & VeryOften \\
\hline g. Cultural Fee & 2.76 & Sometimes \\
\hline Mean $\quad 2.13$ & Very Often \\
\hline F. Fund raising & & \\
\hline a. Cultural Shows & 4.32 & Very Often \\
\hline b. Raffle & 3.14 & Sometimes \\
\hline c. Money Contest & 1.92 & Seldom \\
\hline d. Solicitations & 2.10 & Seldom \\
\hline e. Auctions & 2.09 & Seldom \\
\hline Mean & $\mathbf{2 . 7 1}$ & Sometimes \\
\hline
\end{tabular}

Legend: $4.21-5.00-\quad$ Very Often

$3.41-4.20$ - Often

$2.61-3.41$ - Sometimes

$1.81-2.60$ - Seldom

1.80 and below - Never

The above mentioned findings show that still, it is through the collection of school fees where the state universities and colleges gather more savings. No wonder why there had been moves to increase students' tuition fee in state universities and colleges in the last several years. It could be recalled that enrolling in state universities and colleges was more difficult in the past. Screening was tough that only a few could qualify. Now that students collection has proven the most efficient way to earn income, there is likelihood that state universities and colleges get a little elasticity in their enrolment policies and increase tuition fees or else they will have a trivial chance to earn income for other programs and projects.

The current need of SUCs to increase their enrolment also pause a problem for private higher education institutions which have been partners of the governments in educating the nation from the beginning of the history of higher education. They are not receiving any financial support from the government except for the handful Financial Assistance to Private Education (FAPE) and now, they are being threatened by the realities of promotional campaigns of SUCs who could offer education for much lower tuition fees even though they may occasionally increase tuition.

In general, the 13 state colleges and universities generate income mostly from tuition fees, joint venture, and through the use of economic assets. They also resort to outsourcing and fund raising activities but is frequently done. 


\section{Ml Macrothink}

Journal of Public Administration and Governance

ISSN 2161-7104

2018, Vol. 8, No. 2

Table 5. Summary Table for State Universities and Colleges Percentage Income Utilization

\begin{tabular}{|c|c|c|c|c|c|c|c|c|c|c|c|c|c|}
\hline & & \multicolumn{12}{|c|}{ State Universities and Colleges } \\
\hline & CLSU & NEUST & PAC & DHVTSU & PhilSCA & BSU & BASC & TCA & TSU & RMTU & BPSU & PMMA & ASCOT \\
\hline 1. Instruction & & & & & & & & & & & & & \\
\hline $\begin{array}{l}\text { a. Faculty } \\
\text { and Staff } \\
\text { Development }\end{array}$ & 14 & 13 & 13 & 12 & 13 & 12.5 & 12.5 & 12 & 12.5 & 11 & 12 & 13 & 12 \\
\hline $\begin{array}{l}\text { b.Curriculum } \\
\text { Development }\end{array}$ & 13 & 14 & 10 & 11 & 13 & 12.5 & 12.5 & 12 & 12.5 & 12 & 12 & 12 & 11 \\
\hline $\begin{array}{l}\text { c.Student } \\
\text { Development }\end{array}$ & 11 & 12 & 10 & 11 & 11.5 & 12.5 & 12.5 & 12 & 12.5 & 11 & 11 & 13 & 12 \\
\hline $\begin{array}{l}\text { d.Facilities } \\
\text { Development }\end{array}$ & 12 & 12 & 13 & 12.5 & 12 & 12.5 & 12.5 & 12 & 12.5 & 12 & 12 & 11 & 13 \\
\hline Mean & 50 & 51 & 46 & 46.5 & 49.5 & 50 & 50 & 48 & 50 & 46 & 47 & 49 & 48 \\
\hline $\begin{array}{l}\text { 2. Research } \\
\text { Services }\end{array}$ & 11 & 11 & 12.5 & 11 & 10 & 10 & 10 & 11 & 10 & 11 & 10 & 11 & 10 \\
\hline $\begin{array}{l}\text { 3. Extension } \\
\text { Services }\end{array}$ & 10 & 11 & 12 & 11 & 10 & 10 & 10 & 11 & 10 & 11 & 10 & 10 & 10 \\
\hline 4. Production & 11 & 9 & 12 & 11 & 10.5 & 10 & 10 & 10 & 10 & 11 & 13 & 10 & 12 \\
\hline $\begin{array}{l}5 . \\
\text { Administrative } \\
\text { Services }\end{array}$ & 9 & 9 & 9 & 10.5 & 10 & 10 & 10 & 10 & 10 & 11 & 10 & 10 & 10 \\
\hline $\begin{array}{l}\text { 6. Mandatory } \\
\text { Reserve }\end{array}$ & 9 & 9 & 8.5 & 10 & 10 & 10 & 10 & 10 & 10 & 10 & 10 & 10 & 10 \\
\hline Total & 100 & 100 & 100 & 100 & 100 & 100 & 100 & 100 & 100 & 100 & 100 & 100 & 100 \\
\hline
\end{tabular}

For income utilization, Central Luzon State University (CLSU) allocates half of its income tothe following (according to rank): instruction, faculty and staff development, curriculum, facilities and student development. Only minimal amount was allotted to extension, research, production, administration, and mandatory reserve.

The Nueva Ecija University of Science and Technology (NEUST) utilized most of its income to instruction, with the following distribution according to rank: curriculum, faculty and staff, students, and facilities development. In terms of research and extension, administration services, production, and mandatory reserve, NEUST only allotted minimal budget in these areas.

Pampanga Agricultural College (PAC) shared most of its income to instruction with the following distribution according to rank: faculty and staff development and facilities development. The remaining portion of their income was allotted for research, production, administration and mandatory reserve.

In the case of Don Honorio Ventura Technological State University (DHVTSU), majority of the income were allotted to instruction distributed according to rank: facilities, faculty and staff development, curriculum, and student development, and only minimal was allotted to research, extension, and production as well as to administrative services and only minimal to mandatory reserve.

PhilSCA allotted its income mostly for instruction. Next to it was intended for faculty, staff, curriculum, and student development. Production was given the least allotment, followed by research, extension, administrative services and mandated reserve. 
For Bulacan State University (BSU), Bulacan Agricultural State College (BASC), and Tarlac State University (TSU), majority of their income were allotted appropriately to instruction which was divided equally to the faculty and staff development, curriculum, student development and facilities. They allotted the remaining budget to research, extension, production, administrative services, and mandatory reserve.

Tarlac College of Agriculture's (TCA) allocation for instruction was equally distributed among faculty and staff development, curriculum, student development, and facilities. Next to it was extension and production, followed by research, administrative services, and mandatory reserve.

Ramon Magsaysay Technological University (RMTU) gave the highest generated income to instruction - curriculum and facilities, faculty and staff development, for student development, research, extension, production, and administrative services. The least was allotted to mandatory reserve.

For Bataan Peninsula State University (BPSU), most of the budget was allocated for instruction- faculty and staff development, curriculum, facilities, and student development. Sharing equal allotments out of the remaining income were apportionedto research, extension, administrative services, and mandated reserve.

On the part of the Philippine Merchants Marine Academy (PMMA), appropriated amount for instruction was divided according to rank: faculty, staff, student, curriculum, and facilities development. The remaining income was allocated to research, extension, production, administrative services, and mandated reserve.

For Aurora State College of Technology (ASCOT), most of the income was allotted to instruction in terms of facilities, faculty, staff, student, and curriculum developments. Production received the largest allotment from the remaining areas for income priorities.

As a general finding, the $13 \mathrm{SUC}$ respondents found to be allotting the largest portion of their income to areas that would strengthen instruction like faculty and staff, curriculum, students, and facilities development.

Table 6. Stakeholders Satisfaction Level on Income Utilization

\begin{tabular}{l|c|c}
\hline \multicolumn{1}{c|}{ SUC } & Mean & Interpretation \\
\hline CLSU & 4.65 & Very Satisfied \\
\hline NEUST & 4.80 & Very Satisfied \\
\hline PAC & 4.32 & Very Satisfied \\
\hline DHVTSU & 4.22 & Very Satisfied \\
\hline PhilSCA & 4.21 & Very Satisfied \\
\hline BSU & 4.56 & Very Satisfied \\
\hline BASC & 4.67 & Very Satisfied \\
\hline TCA & 4.51 & Very Satisfied Satisfied \\
\hline TSU & 4.68 & Very Satisfied \\
\hline RMTU & 4.30 & Very Satisfied \\
\hline BPSU & 4.44 & Very Satisfied \\
\hline PMMA & 4.25 & Very Satisfied \\
\hline ASCOT & 4.21 & Very Satisfied \\
\hline Grand Mean & 4.45 & \\
\hline
\end{tabular}


Legend:
4.21-5:00 - Very Satisfied
3.41-4.20 - Satisfied
2.61-3.40 - Moderately Satisfied
1.81-2.60 - Slightly Satisfied
1.80 below - Not Satisfied at all

The table 6 shows that all the stakeholder-respondents were very satisfied about the way the state universities and colleges utilized their income. Among the state universities and colleges which obtained the highest mean were the Nueva Ecija University of Science and Technology (NEUST), 4.80; Tarlac State University (TSU), 4.68; Bulacan Agricultural State College (BASC), 4.67; Central Luzon State University (CLSU), 4.65, and Bulacan State University (BSU), 4.56. The overall mean of the satisfaction level of all the respondents from the different state universities and colleges is 4.45 which can be verbally interpreted as very satisfied.

The satisfaction of the stakeholders in the way the income of the university is utilized tells so much about the effectiveness of handling the state universities and colleges income resources. This being the case, it can be deduced that as a whole the income utilization in the subject schools were very satisfactory as evidenced by their well-rounded curricular design, modern technology-based instructional materials, faculty and student development programs and facilities improvement.

When summarized, all of them were found to be very satisfied about the way the income of the state universities and colleges were utilized. Among them were Nueva Ecija University of Science and Technology (NEUST), Tarlac State University (TSU), Bulacan Agricultural State College (BASC), Central Luzon State University (CLSU), and Bulacan State University (BSU).PhilSCA and ASCOT were the least satisfied among the 13 colleges and universities in Region 3.

Table 7. Performance of the State Universities and Colleges in Region 3 in Terms of the Four-fold Functions

\begin{tabular}{l|c|c}
\hline \multicolumn{1}{c|}{ Functions } & Mean & Interpretation \\
\hline A. Instruction & & \\
\hline 1. Board Examination Result & 4.42 & Very Satisfactory \\
\hline 2. Test Construction & 4.24 & Very Satisfactory \\
\hline 3. Syllabus Preparation & 4.33 & Very Satisfactory \\
\hline 4. Academic Competitions & 4.29 & Very Satisfactory \\
\hline Mean & $\mathbf{4 . 3 2}$ & Very Satisfactory \\
\hline B. Research & & \\
\hline 1. Research Programs & 3.48 & Satisfactory \\
\hline 2. Research Projects & 3.69 & Satisfactory \\
\hline $\begin{array}{l}\text { 3. Research Dissemination (Publication \& \& } \\
\text { Presentation) }\end{array}$ & & Satisfactory \\
\hline
\end{tabular}




\begin{tabular}{l|c|c}
\hline 4. Research Seminars and Trainings & 3.46 & Satisfactory \\
\hline Mean & $\mathbf{3 . 5 1}$ & Satisfactory \\
\hline C. Extension & & \\
\hline 1. Number of Training Activities & 3.59 & Satisfactory \\
\hline 2. Number of Institutional Beneficiaries & 4.11 & Satisfactory \\
\hline 3. Number of Individual Beneficiaries & 3.90 & Satisfactory \\
\hline 4. Timeliness and Relevance of Extension Activities & 3.78 & Satisfactory \\
\hline Mean & $\mathbf{3 . 8 5}$ & Satisfactory \\
\hline D. Production & & \\
\hline 1. Number of Faculty Authors & 3.34 & Moderately Satisfactory \\
\hline 2. Number of Books Authored by Faculty & 3.12 & Moderately Satisfactory \\
\hline 4. Revenue from IGP & 3.03 & Moderately Satisfactory \\
\hline Grand Mean & 2.64 & Moderately Satisfactory \\
\hline
\end{tabular}

Legend:

\subsection{1-5:00 - Very Satisfactory \\ 3.41-4.20 - Satisfactory \\ 2.61-3.40 - Moderately Satisfactory \\ 1.81-2.60 - Slightly Satisfactory \\ 1.80 below- Not Satisfactory at all}

The respondents from the different state universities and colleges in Region III perceived extension as satisfactory, with a total mean of 3.85. All subareas were also claimed to be satisfactory, these were the number of institutional beneficiaries, with a mean of 4.11 ; number of individual beneficiaries, 3.90; timeliness and relevance of extension services, 3.78, and number of training activities, 3.59 .

Production was perceived to be moderately satisfactory by the respondents including all its subareas namely: number of faculty authors, with a mean of 3.34; number of books authored by faculty, 3.12; revenue from IGP, 3.03; and revenue from donations, 2.64. Production received a grand mean of 3.03. This maybe because of limited funds for this activities because as was said in the preceding discussion, the income allocation for these activities were low.

How stakeholders describe the function of state universities and colleges along certain parameters is also another indicator of the quality of state universities and colleges income management. Along this concern, it could be safely said that state universities and colleges, despite strategies and moves to corporatize and earn more, they still never fail to meet the public's expectation of providing the students with very satisfactory education and training. Nonetheless, since they are mandated with four-fold functions, it is only expected that they will also perform well in the areas of research and extension and production other than instructions.

The results demonstrate that in terms of the four-fold functions, instruction was rated very satisfactory in general with all its subareas namely: board examination results; syllabus 
preparation, academic competitions, and test construction. Research with all its sub-areas namely: research projects, research programs, research seminars and trainings, and research dissemination were all rated satisfactory Extension was rated satisfactory. Production was rated "moderately satisfactory" in terms of the following items: number of faculty authors got a mean of 3.34; number of books authored by faculty, 3.12; revenue from IGP, 2.64; and revenue from donations, 2.64. As its general mean, production got a mean of 3.03.

The results show that in terms of production or IGP, the different universities and colleges have enough income because they have enough faculty book authors, enough number of books authored by the faculty, enough profits coming from IGP, and coming from donations. This only indicates that the universities and colleges have self-sustaining capacity to operate. This also signifies that the faculty are satisfied inasmuch as they have extra-income received from the books authored by them.

Table 8. Comparison among State Universities and Colleges in Terms of their Profile, Average Income Generated in the Past Five Years, and their Income Utilization

\begin{tabular}{l|c|c|c|c}
\hline $\begin{array}{l}\text { Point of } \\
\text { Comparison }\end{array}$ & $\begin{array}{l}\text { ANOVA } \\
\text { Value }\end{array}$ & Decision & $\begin{array}{l}\text { Tabular Value } \\
\text { df @ 0.01 ** }\end{array}$ & Interpretation \\
\hline $\begin{array}{l}\text { No. of Programs } \\
\text { Offered }\end{array}$ & 34.05 & Greater & 26.217 & Significant \\
\hline Enrolment Size & 41.91 & Greater & 26.217 & Significant \\
\hline $\begin{array}{l}\text { No. of Teaching } \\
\text { Personnel }\end{array}$ & 32.88 & Greater & 26.217 & Significant \\
\hline $\begin{array}{l}\text { No. of Non- } \\
\text { Teaching }\end{array}$ & 34.44 & Greater & 26.217 & Significant \\
Personnel Income & 40.11 & Greater & 26.217 & Significant \\
\hline $\begin{array}{l}\text { Average Generated in the } \\
\text { Last Five (5) Years }\end{array}$ & & & & Significant \\
\hline Income Generation & 38.23 & Greater & 26.217 & Not Significant \\
\hline Income Utilization & 7.28 & Lesser & 26.217 & \\
\hline
\end{tabular}

Table 8 shows the difference among the state universities and colleges in Region III in terms of their profile, namely: number of programs, enrolment size, number of teaching and non-teaching personnel, and their average income generated in the past five years, and income utilization.

An ANOVA t- value of 34.05 is obtained from the comparison of the number of programs offered by the state universities and colleges in Region III. The t- value is greater than the tabular value of 26.217 which was significant at 0.01 level. This means that the number of programs offered by the state universities and colleges significantly vary. The null hypothesis therefore is rejected. There is a significant difference between the number of programs offered by the state universities and colleges. This also means that there are SUCs offering significantly fewer programs than their other SUC counterparts. Partly, this could be accounted to the nature of specialization the SUC was mandated to offer in the first place. The PhilsCa and the BulSu were two good examples. The programs that PhilsCa should offer to the public must be limited only to those related to aeronautics and there are only few. In 
brief, the range of courses that PhilsCa could offer is not as wide as those that BulSu could offer. BulSu could offer HRM or Criminology or BS Chemistry; PhilsCa could not because it is an aeronautics school. NEUST is another example. Before its conversion to a university, it offered technical and vocational courses only as what its former name implied, Central Luzon Polytechnic College or CLPC, which was mandated by the state to offer varied courses along technical field only. It was only after its conversion into a university that it was allowed to offer courses along the arts sciences area.

The t- value (ANOVA) of 41.91 is derived from comparison of the size of the enrolment of the state universities and colleges in Region III was greater than the tabular value of 26.217 and significant at 0.01 level. The value implied that enrolment size among the state universities and colleges significantly differed. Therefore the null hypothesis was rejected. There was a significant difference between the state universities and colleges in terms of enrolment size. This was because number of enrolment tended to go with the number of program offerings too.

The t- value of 32.88 is derived from the comparison of the number of teaching personnel of the state universities and colleges which is greater than the tabular value and significant at 0.01 level. This means that state universities and colleges significantly differed in the number of teaching personnel. Therefore, the null hypothesis was rejected. There was a significant difference among the state universities and colleges in terms of the number of their teaching personnel.

The same finding as above was true with the number of non-teaching teaching personnel wherein a t- value of 34.33 was obtained from the comparison of the number of non-teaching personnel among the state universities and colleges. The t- value was greater than the tabular value and significant at 0.01 level. This means that the state universities and colleges significantly differed in the number of teaching personnel. Therefore, the null hypothesis was rejected. There was a significant difference among the state universities and colleges in terms of the number of their non- teaching personnel.

In terms of average income generated in the past 5 years, a t- value of 40.11 is derived. It is greater than the tabular value and significant at 0.01 level. Therefore, the null hypothesis is rejected. There is a significant difference among the state universities and colleges in terms of their average income in the last five years.

The significant differences observed among SUCS in terms of the above mentioned variables of program offerings, size of enrolment, number of teaching and non teaching personnel as well as income earnings brought the researches to think that these variables were generically or basically dependent upon the SUC's nature or basic mandate.

In terms of the modes for income generation, a t- value of 38.23 was derived which was greater than the tabular value of 26.217. This means that there is a significant difference among the state universities and colleges in terms of mode of income generations.

On income utilization, a t- value of 7.28 is obtained which is lesser than the tabular value. It indicates that there was no significant difference among the SUCs in terms of income 
utilization. Therefore, the null hypothesis was accepted. The SUCs concerned tended to have similarities in the way they prioritize when utilizing their income. This could be because SUCS were bound by common rules and expectations that they tended to be similar in focus and prioritization; unlike in the other profile variable where differences were inherent and evident from the beginning.

Table 9. Correlation between the Employees Satisfaction Level and the Described State Universities and Colleges' Performance in terms of their Four-Fold Functions

The table below shows the correlation between the employees' satisfaction level and the universities and colleges' performance in terms of instruction, research, extension, and production.

\begin{tabular}{l|l|l}
\hline Correlation & $\begin{array}{l}\text { Employees' Satisfaction in } \\
\text { Income Utilization }\end{array}$ & Interpretation \\
\hline Instruction & $0.894 * *$ & $\begin{array}{l}\text { Significantly Correlated @ } \\
0.01 \text { level }\end{array}$ \\
\hline Research & $0.419 * *$ & $\begin{array}{l}\text { Significantly Correlated @ } \\
0.01 \text { level }\end{array}$ \\
\hline Extension & $0.527 * *$ & $\begin{array}{l}\text { Significantly Correlated @ } \\
0.01 \text { level }\end{array}$ \\
\hline Production & $0.771 * *$ & $\begin{array}{l}\text { Significantly Correlated @ } \\
0.01 \text { level }\end{array}$ \\
\hline
\end{tabular}

Based on the findings in terms of the relationship between the employees' satisfaction and the fourfold SUC functions, between the performance of the state universities and colleges in terms of instruction and the employees' satisfaction when it comes to income utilization, an $r$ value of 0.894 was obtained which was significant at 0.01 level; between the performance in research and the satisfaction of the employees in income utilization, there was an $r$ value of 0.419 obtained and significant at 0.01 and with a high level of correlation.

There was an $r$ value of 0.527 derived from the relationship between extension performance of the state universities and colleges and the satisfaction of the employees in income utilization was significant at 0.01 level; and lastly, between the performance of the state universities and colleges in terms of production and the employees' satisfaction level, an $r$ value of 0.771 was obtained which was significant at 0.01 level.

Based on the findings from the above, it was concluded that the SUCs in Region III varied in terms of their program offerings, enrolment size, number of teaching personnel, number of non-teaching personnel, and average income in the last five years. They generate income mostly from tuition fees, joint venture, and use of economic assets. It was only sometimes that they made outsourcing, and fund raising activities. They were found to be allocating the largest portion of their income to areas that would strengthen instruction like, faculty and staff, curriculum students and facilities development. The areas of research, extension and production tend to be given lesser priority.

The respondents were very satisfied with the income utilization in their respective SUCs. However those from Nueva Ecija University of Science and Technology (NEUST), Tarlac State University (TSU), Bulacan Agricultural State College (BASC), Central Luzon State 
University (CLSU), and Bulacan State University (BSU) were the most satisfied; while those from PhiSCA and ASCOT were the least satisfied.

There is a need to improve the performance of the SUCs in Region 3 primarily along the line of production, research and extension.

The hypothesis of no significant difference among SUCs in terms of profile variable is rejected. SUCS differ significantly in terms of their respective profiles and income utilization is not significantly different.

The relationship between the employees' satisfaction and the four fold functions of state universities and colleges showed that there was a significant link between the performance of the state universities and colleges and the employees' satisfaction. The satisfaction level of the respondents could be an indicator of their perception of the SUCs performance along their four-fold functions.

\section{Conclusion and Recommendations}

From the conclusions drawn, the following are highly recommended: that the different colleges and universities must employ mode of income generation that is most fitted for them; SUCs which could not possibly have bigger size of enrolment due to constraints of mandated program offering must not rely on school fees alone to earn income; they should be more resourceful and aggressive in trying other modes such as utilization of economic assets fund raising or joining venture with other institutions; they should also strengthen their link up with other sponsoring agencies or beneficiaries and must likewise activate their alumni or PTA association for major projects programs and activities; SUCs in region 3 should invest more to intensify their research programs and projects as research may also result to additional income; extension programs should also be given more priority as the community can also be a potential partner in sourcing out income where both the school and the community can be benefited; it may also be beneficial to invest more in production as in the principle of money begets money. All the SUCs have to intensify their production activities by first identifying a more lucrative production investment and by utilizing a workable, functional and effective marketing plan.

Since Nueva Ecija University of Science and Technology (NEUST),Tarlac State University (TSU), Bulacan Agricultural State College (BASC), Central Luzon State University (CLSU), and Bulacan State University (BSU) were found to be the most satisfied with their respective school's income utilization, other SUCs may ask advice from them following the principle of peer mentoring likeadopting the attitude of openness to mentoring; organizing themselves together in the form of a regional association focusing alone on corporatization strategies with the aim of developing a more satisfactory income generation and utilization among SUCs. The association can be like the SCUAA or State Colleges and Universities Athletic Association in principle. This may be termed as SUCs 3 Association for Corporate Development (SUCS 3 ACD)

Since it was concluded that SUCs need to improve performance along the line of production, research and extension, it is suggested that more administrative support be given to these 
areas: that state universities and colleges utilize their respective income in the direction of research and extension. Income may also be used to fund researches and extension activities. This may likewise be used as incentive for the faculty so as to motivate them to do researches or involve themselves in extension activities; that there should be an initiative coming from school administrators to shift the paradigm of the stakeholders who seemed to be contented with how the income of their respective schools was being utilized. This only goes to show that they do not believe much in research, which should not be the case because these two were also indicators of quality instruction; and that the state universities and colleges should assign a focal person or a director that oversees the production of the school. It should always be remembered that production like research and extension is also an indicator of quality of instruction.

Since the SUCs in Region 3 differ significantly in terms of their respective profile, it is strongly recommended that the SUCs must create a committee to study potential approaches to intensify their corporatization strategy according to their unique characteristics and to devise a research-based corporatization plan; and that there should be another study to explain the impact of significant difference among the number of programs offered by the state universities and colleges.

The study proved that there was a significant link between the performance of the state universities and colleges and the employees' satisfaction. Therefore, they should be involved in planning and organizing programs and projects in terms of the four-fold functions of the state universities and colleges. The study showed that there is a correlation between employees' satisfaction and the manner SUCs utilized their income from private- like operations. However, the study focused only on the four fold functions and linked the same to their potential impact on motivations. Other studies in higher education corporatization strategies may be done by other researchers using as variables: salaries received, wages, packaged of benefits and other fringe benefits having direct rewards on the employees. The potential sources of which are from income generated from corporatization strategies but have direct influence on employees' motivations which the present study failed to measure.

\section{References}

Alvaran, A. (2002). Resource Generation of Selected State Universities and Colleges: An assessment

Bok, D. (2003). Universities in the Marketplace: The Commercialization of Higher Education. Princeton, NJ: Princeton University Press, 2003.

Buchbinder, H. (1990). Social knowledge and market knowledge: universities in the information age. Gannett Center Journal, 5, 17-29.

Duka, C. (2005). Review for the Licensure Examination for Teachers, Manila Review Institute, Inc. Manila, Philippines

Fronda, J., Gabriel, A., \& Loria, S. (2018). The Philippines at the Crossroads to Economic Globalization. Open Journal of Social Sciences, 6, 128-151. 


\section{Macrothink}

https://doi.org/10.4236/jss.2018.61010

Gabriel, A. G., \& Claudio, E. G. (2016) Study Manual on Politics, Governance and Government with Philippine Constitution, Nueva Ecija University of Science and Technology Printing Press, Cabanatuan City, Philippines.

Ginsberg, B. (2011). The Fall of the Faculty: The Rise of the All-Administrative University and Why It Matters. New York: Oxford U P, 2011.

Malate, R. (2009). Impact of Corporatization on Higher Education

Mills, N. (2002). The Corporatization of Higher Education

Padua, R.N. (2003). International higher education quality assurance practices: Situating the Philippine system.

Steck, H. (2003). Corporatization of the University: Seeking Conceptual Clarity. Annals of the American Academy of Political and Social Science, 585(Jan.2003), 66-83. https://doi.org/10.1177/0002716202238567

Villabroza, J. M. P. (2002). Rationalization of public higher institutions: towards greater Efficiency http://www.insidehighered.com.

\section{Copyright Disclaimer}

Copyright for this article is retained by the author(s), with first publication rights granted to the journal.

This is an open-access article distributed under the terms and conditions of the Creative Commons Attribution license (http://creativecommons.org/licenses/by/4.0/). 